\title{
Public Sector and Its Role on Employment Generation in Bangladesh
}

\author{
Soeb Md. Shoayeb Noman \\ Senior Lecturer, Department of Business Administration, Uttara University House-05, Road-12, Sector-06, \\ Uttara, Dhaka-1230, Bangladesh
}

\begin{abstract}
This research deals with analysis of public sector and its impact on overall employment generation in Bangladesh. Secondary data from Bangladesh Bureau of Statistics, CIA world factbook, Bangladesh Bank and Bangladesh government's annual reports is mainly used for this study. The study adopted descriptive statistics, regression and correlation analysis on employment, population, labor force, service sector and public sector employment. The objectives of the study are to describe the trend of the variables; examine the impact of public sector and other variables on overall employment and to make recommendations based on the research findings. The results revealed that there has been small fluctuation in the trend of employment, population, labor force, service sector and public sector employment considered with reference to the year 1974-2010. The results also show that $99.9 \%$ of the variation (model 1) has been explained by the explanatory variables, $82.4 \%$ of the variation in dependent variable (model 2) has been explained by the explanatory variable. The results further show that public sector has positive relationship with employment which shows that a unit increase in the aforementioned variable will lead to unit increase in employment. The correlation results further showed that population, labor force and service sector are significant at 1\% probability level. The study concluded that populations, labor force, service sector and public sector are significant variables that affect employment generation in Bangladesh.
\end{abstract}

Keywords: Employment generation, government policy, public institutions and dynamic estimation

\section{Introduction}

Bangladesh has a high population density compared to the other countries in the world. But it has a huge potential to perform very well as a developing country. It has a GDP growth rate of more than $6 \%$ over the last five years or so (Bangladesh Economic Review, 2013). To continue and accelerate this high economic growth it is necessary to maintain a low level of unemployment.

At the beginning of the millennium, the World Public Sector Report 2001 published by United Nations asserted that countries with the most developed and comprehensive public sectors, compared to the weak, inefficient and sluggish ones, have been more successful in reaping the benefits of globalization (United Nations, 2001). But public service efficiency is of diverse nature in developed and developing countries because of different attributes of public administrative systems (Jreisat, 2002). It is well understood that without an efficient, capable and service oriented public administration, it would be impossible to attain the Millennium Development Goals (MDGs). The Millennium Declaration also recognizes good governance, of which public administration is a central part, as the means for achieving the goals of the Declaration (Alam, 2006).

Bangladesh is a country with considerable potential that is trapped in a low growth cycle. There is now clear worldwide evidence on the significant and positive correlation between efficiency of public institutions and economic growth. It is also becoming increasingly clear that the inability of Bangladesh to get out of the low growth trap is largely due to the weak implementation capacity and inefficiencies of public institutions, the government's inability to plan and manage key reforms, and its predilection to manage economic activities at the micro-level. Bangladesh will be a different country as it enters the 21 st Century. This is not a matter of choice. The internal pressures from a rapidly growing, and more demanding, population will fuse with the external pressures, from a much more competitive global economic environment, to create new opportunities and new demands. The public sector, as presently constituted, will not be able to cope. (Kibria, Rahman \& Chowdhury, 1996)

Though the size of the public service has increased over the years along with the complexities stemming from the dynamics of different types of public administration models, it still reflects the divergent hereditary traditions it inherited from the "feudal chiefs, independent kings, landlords, and representatives of the rulers at Delhi and Islamabad as well as Great Britain" (Huque and Ahmed, 1992). Like most other developing countries, Bangladesh possesses an overdeveloped bureaucratic apparatus as its colonial legacy in spite of all the postcolonial rehabilitation and reforms in the administrative superstructure along with underdeveloped political, economic and cultural realms (Haque, 1997). 


\section{Basic Idea about Bangladesh}

Bangladesh is situated in Southern Asia, on the delta of the 2 largest rivers on the Indian subcontinent - the Ganges and Jamuna (Brahmaputra). It is the seventh most populous country in the world and is mostly densely inhabited (Bangladesh Economic Review, 2013). The poverty level has fallen by more than $20 \%$ which was helped by its prominent agricultural sector and contribution of the garments sector (Bangladesh Economic Review, 2013).

It borders with India in the west, north, and east, with Myanmar in the southeast, and with the Bay of Bengal in the south. The country's area is 144,000 square kilometers (55,598 square miles), and it is divided into 7 administrative divisions (Dhaka, Chittagong, Khulna, Barisal, Rajshai, Sylhet and Rangpur) and 10 major municipal corporations. Comparatively, the territory of Bangladesh is slightly greater than the state of New York. Bangladesh's capital city, Dhaka, is located in the central part of the country. Bangladesh occupies the eastern part of the Bengal region (the western part of the region is occupied by the Indian state of West Bengal), which historically was part of the great civilizations in the northeast of the Indian subcontinent.

The district still remains the most generally used unit of administration. For administrative convenience, some adjoining districts are considered to comprise a division, while a district is subdivided into several police stations (upazila). Thus, division, district, and upazila comprise the administrative sub-units of the country; several upazila constitute a district, and some ten to twelve districts constitute a division. In 1994, the average population of an upazila was 250,000; the average population of a district was 2 million and that of a division was 24 million. (World Bank, 1996)

As Bangladesh is one of the Least Developed Countries (LDCs), its economy is characterized as poor and developing, despite several improvement efforts at the national and international levels. In 2008, the per capita income of the country stood at US\$520, while the world average was \$10,200 (Sixth Five Year Plan, 2011). As of 2009, Bangladesh had an estimated population of 146,700,000 people (Sixth Five Year Plan, 2011). The literacy rate in the country is about $41 \%$ (Sixth Five Year Plan, 2011). The poverty rate is very high. However, over the years, there has been considerable improvement in the poverty level as well as health and education levels.

The Bangladeshi economy is helped by its big garment sector, which contributes more than two-thirds of the country's trade (Sixth Five Year Plan, 2011). The major challenge to prosperous growth is the vulnerability of the land to cyclones and floods. However, even with such challenges, Bangladesh has experienced a growth rate of 5\% since 1990 (Sixth Five Year Plan, 2011). This growth has been backed by remittances from expatriates as well. Over 40\% of Bangladesh's GDP comes from the service sector (Sixth Five Year Plan, 2011).

Since 1975, there has been a two-fold increase in the per-capita GDP (Bangladesh Economic Review, 2013). During the 2008 global economic recession, Bangladesh managed to stay flexible. According to the Bangladesh Bureau of Statistics (BBS), there was an increment of \$62 in the per capita GDP in FY2009 from US\$559 at the end of FY2008. Fiscal 2009 registered per capita income of US\$621. About 25\% of the country's GDP in 2009 came from remittances of expatriates, totaling $\$ 9.7$ billion and garment exports worth $\$ 12.3$ billion (BBS, 2012).

According to the World Bank, Bangladesh has achieved a growth rate of 5.7\% in FY2009 (CIA, 2011). The country has registered significant expansion in its middle class. The consumer industry has grown considerably. The increasing foreign direct investment highlights the growth rate of the Bangladesh economy (CIA, 2011).

\section{Statement Of The Problem}

There is consent of opinion in literature on the impact of public sector or public policies on employment generation in developed and developing countries of the world. However, there has been contrasting opinions on how much influence that the public sector has on aggregate economic activities in any economy. Despite the demonstrated efficacy of public sector in other developed economies of the world as policies; other policies have not been sufficiently and adequately yielded any encouraging employment generation in Bangladesh.

In Bangladesh, there have been very few empirical studies regarding efficacy of the public policies. The purpose of this study is, therefore, to test empirically the effectiveness of the public sector on employment generation in Bangladesh.

The general objective of the study is to examine the impact of public sector on employment generation in Bangladesh.

Specific objectives of the study are:

- to determine the trend of public sector employment over the years (1974-2010),

- to examine the impact of public sector employment on overall employment in Bangladesh and 
- to make recommendations based on research findings on how public sector can enhance overall employment and economic development in Bangladesh.

\section{Statement Of The Hypothesis}

$\mathbf{H}_{\mathbf{0}}$ : There's no significant impact of public sector on employment generation in Bangladesh.

$\mathbf{H}_{\mathbf{1}}$ : Public sector has significant impact on employment generation in Bangladesh.

\section{Significance Of The Study}

The study is very relevant as it will empirically show the influence of public sector and public administration policies in Bangladesh on employment generation. However it is important to study the effect of the government policies to ensure the efficiencies on the employment generation or even in economic growth. The purpose of this study is to fill the gap by testing the comparative effect of the public sector reforms in the case of developing economy like Bangladesh. This will also contribute to knowledge and serve as a framework for government policies with a view to enhancing employment generation and economic development.

\section{Empirical Review}

Public Service Commission (PSC) of Bangladesh, a constitutional body, is the other central agency responsible for recruiting suitable candidates for appointment to the civil service by the MoE. It is also involved in the decision processes relating to other PHRM matters such as promotion, posting, transfer, discipline and appeal of the government servants (Ahmed, 2006).

So far, studies on public management reforms have largely been restricted to the "how" of government. Any effective reform program has to recognize the link between the "how" and "what" of government. In reforming countries, the "what" has influenced the approach to the "how". At another level, the ultimate test of doing the "how" better is whether it supports the government and community in making better decisions about the "what". (Kibria, Rahman \& Chowdhury, 1996)

Mohammad Ehsan primarily aims to (a) survey the challenges of the structural and management aspects of PHRM of Bangladesh and (b) explore whether the theoretical framework proposed by the World Public Sector Report (WPSR) 2005 is applicable and implementable in Bangladeshi perspective. In doing so, the paper has been divided into few sections. After the introductory discussions, the paper focuses on the theoretical perspective and associated themes derived from the United Nations Department of Economic and Social Affairs' (UN/DESA) WPSR 2005 titled Unlocking the Human Potential for Public Sector Performance (Ehsan, 2008).

The key public sector issues were studied by a group of Bangladeshi citizens with knowledge of and interest in public sector reforms. The reports were expected to: enhance the quality and depth and breadth of the on-going debate within the country on the role of the state and public sector performance; raise awareness in the body politic on the linkage between public sector performance and growth; provide the cross-country experience and analytical underpinnings for reform of the public sector; and help accelerate the momentum for change and strengthen those forces in Bangladesh which are pressing for change. (Kibria, Rahman \& Chowdhury, 1996)

Private Sector Development \& Finance Division Country Department 1 - South Asia Region published the report that generates ideas for changes to GOB's on-going Public Sector reform initiatives potentially enabling them to have an impact which has thus far been elusive. Indeed, these initiatives lacked the broader context and focus on actions essential to induce behavioral change in organizations. To aid the incoming Government in drawing up an agenda for public sector reform, it makes: recommendations on priority areas of reform during the short-term; and provides advice on preparation of a comprehensive medium-term Action Plan in context of a long-term vision of the redefined role of the state. (Kibria, Rahman \& Chowdhury, 1996)

Mukherjee et al. (2001) summarizes the responses of Bangladeshi class I (highest level) public sector officials to a survey seeking opinions on a number of civil service issues, from personnel management practices to rewards and disciplinary actions, and from employees, sources of income to the budget environment and procurement processes. Survey results show instances in Bangladesh's civil service where professional conduct is perceived to be sacrificed at the expense of personal and political concerns. Surveyed officials express a concern with patronage appointments in the recruitment of Class III and IV staff and unfavorable postings and transfers at the higher level (Mukherjee et al., 2001).

Jahan and others examines the structure, reforms and challenges of the contemporary Bangladesh Civil Service. They provide an overview of the public administration system; an evaluation of reforms and innovations that have been "allowed"; the present recruitment procedure; and the extent and impact of politicization. Recruitment and politicization are the key problems identified and discussed. To explore these problems further they conducted qualitative, interview-based primary research with university graduates, and entry-level, mid-career and retired civil servants. (Jahan, 2006) 


\section{Research Methodology}

The area of study is Bangladesh. The sources of data were mainly from secondary source. These data were from the Bangladesh Bureau of Statistics, journals, CIA world factbook, Bangladesh Bank and Bangladesh government's annual reports. Time series data spinning from 1974 to 2010 were gathered on four independent variables. Population, labor force, service sector employment and public sector employment stands as the independent variable. Our dependent variable is overall employment in Bangladesh.

The techniques adopted in the study are:

- Descriptive statistics

- Ordinary least square method

Descriptive statistics: This involves the use of charts to show the trends of all macro-economic variables (Overall employment, population, labor force, service sector employment and public sector employment).

Model specification: Reading through the various works and analyses of the various writers. It is possible to specify our empirical model in the following manner:

$E_{t}=f(P E)$ Implicit functions

Where, $\mathrm{E}$ is a measure of aggregate level of employment, PE measures of public sector employment.

The model is explicitly specified as:

Model $1 \mathrm{E}=\beta_{0}+\beta_{1} \mathrm{POP}+\beta_{2} \mathrm{LF}+\beta_{3} \mathrm{SE}+\beta_{4} \mathrm{PE}+\mathrm{e}_{\mathrm{t}}$

Model $2 \mathrm{E}=\mathrm{Y}_{0}+\mathrm{Y}_{1} \mathrm{PE}$

Where,

$\mathrm{e}_{\mathrm{t}}=$ Error term

$\beta_{0}, \beta_{1}, \beta_{2}, \beta_{3}$ and $\beta_{4}$ are the coefficient of the independent variables

$\mathrm{E}=$ Aggregate level of employment

$\mathrm{POP}=$ Population (million)

$\mathrm{LF}=$ Labor Force (million)

$\mathrm{SE}=$ Service sector employment (million)

$\mathrm{PE}=$ Public sector employment (million)

The model is estimated using Ordinary Least Square techniques (OLS). It is subjected to a dynamic estimation using the lag structure of the variables. There will be determination of the existence of substantial comovements among time series variables. The reason for this is that when the dependent and independent variables have unit roots, traditional estimation method, using observations on levels of those variables would likely find a statistically significant relationship even when meaningful "economic" linkage is absent (Akinlo and Odusola, 2003). To determine the time series properties of the variables the data is be subjected to Augmented Dickey-Fuller Unit Root Test (Dickey and Fuller, 1981). The univariate time series behavior will therefore be determined.

\section{Results And Discussion}

Employment (1974-2010): Figure 1 shows the employment trend. In 1974, the level of employment was very low (19.4 million), then it increased gradually since 2009. Inflation is inversely related to growth in the economy i.e. the higher the inflation rate, the lower the economy growth and the lower the inflation rate, the higher the economy growth. 
Figure 1: Trend of employment, population, labor force, service sector and public sector in Bangladesh

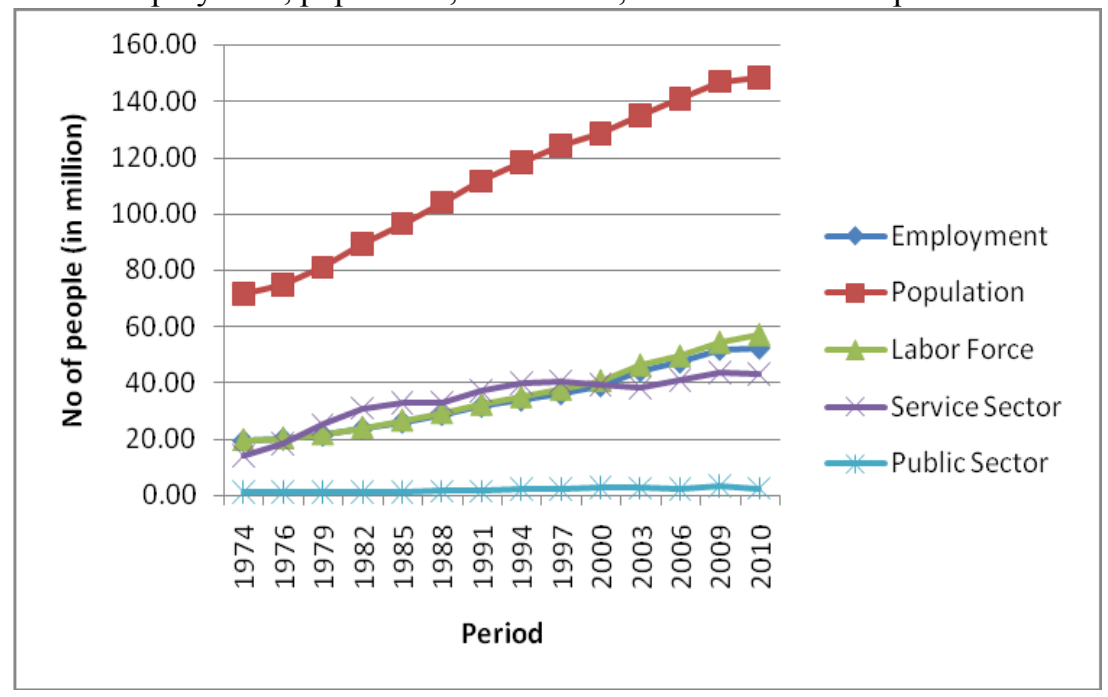

Growth in Population (1974-2010): The size of the population in 1974 was 71.5 million and increased upwards since 2010 (148.2 million). There is a direct relationship between population and employment and a positive relationship between population and employment.

Labor Force (1974-2010): There has been a continuous increase in the labor force as the population increases between the periods of 1974-2010.

Service Sector (1974-2010): Figure 1 shows that employment in the service sector continues to increase from 1974 to 1997, but the rate was not even. In the year 1997 it starts to decline and continues till 2003, afterwards it increases up to the year 2009. In 2010 it reduces slightly.

Public Sector (1974-2010): The public sector employment remains quit steady till 1991. After this there is a sharp increase since 2000, then it fluctuates heavily. In 2009 it reaches its pick level.

Employment and other variables: The result of Table 1 reveals that there is inverse relationship between employment and service sector, whereas there is a positive relationship between employment and other variables (population, labor force and public sector). Thus, population, labor force and public sector will increase employment while holding service sector constant, but the reverse is the case for service sector, when population, labor force and public sector are held constant. The t-statistics shows the significant relationship between employment and the estimated variables (population, labor force and public sector). R-square value shows that $99.90 \%$ of variation in employment is being explained by the explanatory variables. F-statistics value of 2273.638. Though, only the labor force is showing high level of significant on the employment.

Table 1: Regression results on employment, population, labor force, service sector and public sector

\begin{tabular}{|c|c|c|c|c|c|c|}
\hline \multicolumn{2}{|c|}{ Regression Statistics } & & & & & \\
\hline Multiple R & 0.999505565 & & & & & \\
\hline R Square & 0.999011375 & & & & & \\
\hline Adjusted R Square & 0.998571986 & & & & & \\
\hline Standard Error & 0.437180641 & & & & & \\
\hline Observations & 14 & & & & & \\
\hline \multicolumn{7}{|l|}{ ANOVA } \\
\hline & Df & SS & MS & $\mathrm{F}$ & Significance $\mathrm{F}$ & \\
\hline Regression & 4 & 1738.213 & 434.5534 & 2273.638 & $1.65 \mathrm{E}-13$ & \\
\hline Residual & 9 & 1.720142 & 0.191127 & & & \\
\hline \multirow[t]{2}{*}{ Total } & 13 & 1739.934 & & & & \\
\hline & Coefficients & Standard Error & $\mathrm{t}$ Stat & P-value & Lower $95 \%$ & Upper $95 \%$ \\
\hline Intercept & -0.88460504 & 1.507892 & -0.58665 & 0.571858 & -4.29569 & 2.526484 \\
\hline Population & 0.07326926 & 0.054328 & 1.348655 & 0.210402 & -0.04963 & 0.196167 \\
\hline Labor Force & 0.75653362 & 0.073022 & 10.36036 & $2.66 \mathrm{E}-06$ & 0.591346 & 0.921721 \\
\hline Service Sector & -0.02804788 & 0.060141 & -0.46637 & 0.652031 & -0.1641 & 0.107999 \\
\hline Public Sector & 0.42549845 & 0.425785 & 0.999327 & 0.343745 & -0.53769 & 1.388691 \\
\hline
\end{tabular}


Summary of regression results:

Model $1 \mathrm{E}=\beta_{0}+\beta_{1} \mathrm{POP}+\beta_{2} \mathrm{LF}+\beta_{3} \mathrm{SE}+\beta_{4} \mathrm{PE}$

$\mathrm{E}=-0.8846+0.0733 \mathrm{POP}+0.7565 \mathrm{LF}-0.0280 \mathrm{SE}+0.4254 \mathrm{PE}$

$\begin{array}{lllll}(-0.5866) & (1.3486) & (10.3604) & (-0.4664) & (0.9993)\end{array}$

R-squared $=0.9990(99.90 \%)$

F-statistics $=2273.638$

Figures in interpolation are t-statistics

Employment and Public Sector Employment: The result in Table 2 shows the positive relationship between employment and public sector employment, which implies that the public sector employment has significant relation with overall employment. The co-efficient of determination R-squared result reveals that $82.40 \%$ of the variations in Employment are being explained by Public Sector Employment. The f-statistics also shows that the model is significant. However, the model also revealed positive serial correlation as shown in the value of Durbin Watson test of 1.34 .

Table 2: Regression results on employment and public sector

\begin{tabular}{|c|c|c|c|c|c|c|}
\hline \multicolumn{2}{|c|}{ Regression Statistics } & & & & & \\
\hline Multiple R & 0.907767259 & & & & & \\
\hline R Square & 0.824041396 & & & & & \\
\hline Adjusted R Square & 0.809378179 & & & & & \\
\hline Standard Error & 5.051041783 & & & & & \\
\hline Observations & 14 & & & & & \\
\hline \multicolumn{7}{|l|}{ ANOVA } \\
\hline & $\overline{\mathrm{Df}}$ & $\mathrm{SS}$ & MS & $\bar{F}$ & Significance F & \\
\hline Regression & 1 & 1433.777266 & 1433.777266 & 56.197859 & $7.26741 \mathrm{E}-06$ & \\
\hline Residual & 12 & 306.1562771 & 25.51302309 & & & \\
\hline \multirow[t]{2}{*}{ Total } & 13 & 1739.933543 & & & & \\
\hline & Coefficients & Standard Error & t Stat & P-value & Lower 95\% & Upper $95 \%$ \\
\hline Intercept & 2.615442507 & 4.402076771 & 0.594138322 & 0.5634531 & -6.975858828 & 12.2067438 \\
\hline Public Sector & 14.52007 & 1.936907257 & 7.496523105 & 7.267E-06 & 10.29991163 & 18.7402284 \\
\hline
\end{tabular}

Model $2 \mathrm{E}=\mathrm{Y}_{0}+\mathrm{Y}_{1} \mathrm{PE}$

$\mathrm{E}=2.6154+14.5200 \mathrm{PE}$

(0.5941) (7.4965)

R-squared $=0.8240(82.40 \%)$

F-statistics $=56.1978$

D. $\mathrm{W}=1.34$

Correlation matrix of the variables: This shows the relation between Overall employment and other variables (population, labor force, service sector employment and public sector employment).

Table 3: Correlation matrix on employment with population, labor force, service sector and public sector

\begin{tabular}{|l|r|}
\hline & Employment \\
\hline Employment & 1 \\
\hline Population & 0.9824 \\
\hline Labor Force & 0.9990 \\
\hline Service Sector & 0.8540 \\
\hline Public Sector & 0.9077 \\
\hline
\end{tabular}

Employment and Population: The result of Table 3 reveals that there is strong positive correlation $(0.982)$ between population and employment.

Employment and Labor Force: There is also positive correlation (0.999) between labor force and employment. More so, labor force does have significant relationship with employment. Thus, does highly contribute to the employment. 
Employment and Service Sector: The result of Table 3 reveals that there is a positive correlation $(0.854)$ between service sector and employment. More so, service sector has less significant relation with the employment than the other variables.

Employment and Public Sector: The correlation result in Table 3 shows that public sector is significant at 1\% probability level and also strongly positively related $(0.907)$ to the employment.

\section{Limitations Of Analysis}

This research has some limitations, such as -

- All the data used here are secondary data, no primary data was used. There are some missing values which were replaced by the mean values.

- The value of $\mathrm{R}^{2}(99.90 \% \& 82.40 \%)$ is very high, which is unusual for this type of research.

\section{Summary Of Findings}

The study has been able to find out that although there has been small fluctuation in the trend of sector based variables in Bangladesh (i.e., population, labor force, service sector employment, and public sector employment) considered with reference to the year 1974 to 2010, although there are some gap between the periods.

In model $1,99.90 \%$ of the variations in dependent variable were explained by the explanatory variable while $82.40 \%$ of the total variation has been explained by the explanatory variables in model 2 as indicated above. The result further shows that all the variables (i.e., population, labor force, service sector employment and public sector employment) have positive relationships with overall economic employment, which shows that a unit increase in those variables will lead to a unit increase in employment. The correlation analysis shows that labor force, population, public sector employment and service sector employment is significant at $1 \%$ probability level. But the degree of correlation is different for different variables.

As compared to labor force, employment grew at a slightly slower pace of 2.8 percent annually. As a result, the unemployment rate, traditionally defined, increased modestly, 15 reaching 2.1 million people, which is about 4 percent of the labor force. This relatively modest unemployment rate, however, hides the true employment challenge in Bangladesh. (Sixth Five Year Plan, 2011)

The analysis of the Ordinary Least Square methods (OLS) showed that public sector is positively related to the growth in employment as well as the other variables. Thus, these variables contribute to the overall employment generation in Bangladesh.

\section{Conclusion}

Poverty reduction is the most important socio-economic challenge for Bangladesh. It has been determined for a long time to reduce the rate of poverty and to improve the living standards of its millions of penniless citizens. Bangladesh has made substantial progress in reducing poverty, where the percent of population living below the poverty line went down from more than 80 percent in early 1970 s to 31.5 percent in 2010 (BBS, 2012).

Employment is the major instrument for poverty reduction in Bangladesh. Labor force (age $15+$ ) in Bangladesh increased from around 19.7 million in 1974 to 73.87 million in 2013 (CIA, 2013), the latest available year for Labor Force Survey (LFS). That gives an annual long term trend growth rate of 2.9 percent. The labor force growth rate was roomier in recent years owing to the changing demographic structure in the working age group as well as an expanding female participation rate. Thus, the average annual growth of labor force between 2000 and 2009 was 3.2 percent (BBS, 2012).

The research study examined the impact of public sector on employment generation in Bangladesh with particular reference to the period of 1974-2010. The study concluded that population; labor force, service sector and public sector are significant variables that affect employment generation in Bangladesh. This also conforms to the a priori expectations that the public sector has some role to play. The study therefore recommends that in order to put Bangladesh in such economic condition where the government can control the unemployment problem and put the country into a sustainable economic growth and development, the government must co-ordinate with the private sector in order to enhance the welfare of the residents.

Foundation of human capital for sustainable economic growth and poverty mitigation has been a crucial developmental instrument in Bangladesh since independence. Successive education sector plans and strategies focused on enhancing access and quality of education along with emphasis on public sector development and better utilization of scarce resources. Enlightening education quality was perceived as the most precarious challenge for meeting the skills and knowledge requirements of the national economy. 


\section{References}

[1]. Ahmed S.G., 2006, "Bangladesh Public Service Commission" in Sirajul Islam (ed.) Banglapedia: National Encyclopedia of Bangladesh, Dhaka: Asiatic Society of Bangladesh.

[2]. Akinlo, A.E. and A.T. Odusola, 2003, "Assessing the impact of Nigeria's naira depreciation on output and inflation", Appl. Econ., 35(6): 691-703.

[3]. Alam M., 2006, "Role and Effectiveness of Bangladesh Civil Service in Achieving Millennium Development Goals", Preparatory Assistance on Developing Civil Service Capacity for the 21 st Century Administration, London: Public Administration International, p.9.

[4]. Bangladesh Bureau of Statistics, 2012, "Population Census 2011 National Report”, Planning Division, Ministry of Planning, Bangladesh, July.

[5]. Bangladesh Economic Review, 2013, Economic Adviser's Wing Finance Division, Ministry of Finance, Government of the People's Republic of Bangladesh, July.

[6]. CIA, 2011, The World Factbook, Central Intelligence Agency, United States of America, 2011, www.cia.gov/library/publications/download/download-2011

[7]. CIA, 2013, The World Factbook, Central Intelligence Agency, United States of America, 2013, www.cia.gov/library/publications/download/download-2013

[8]. Dickey, D. and W. Fuller, 1981, "Likelihood ratio statistics for autoregressive time series with a unit root", Econometrica, 49: 10571072 .

[9]. Ehsan M., 2008, "Public Sector Human Resource Management In Bangladesh: Challenges And Opportunities In Light Of The Wpsr 2005", Public Sector Human Resource Management In Bangladesh, Asian Affairs, Vol. 30, No. 4: 50-75, October-December.

[10]. Haque, M.S., 1997, "Incongruity between Bureaucracy and Society in Developing Nations: A Critique", Peace \& Change, Volume 22 , No. 4, p.432.

[11]. Huque A.S. and Ahmed F., 1992, "Public Personnel Administration: Tradition, Problems and Issues in Bangladesh", Asian Journal of Public Administration, Volume 14, No. 1, p.36.

[12]. Jahan F., 2006, "Public administration in Bangladesh", CGS Working Paper CGS WP 1, Centre for Governance Studies BRAC University Dhaka, Background Paper for The State of Governance in Bangladesh, December.

[13]. Jreisat J., 2002, "Comparative Public Administration and Policy", Colorado: Westview Press.

[14]. Kibria R., Rahman M., and Chowdhury T.E., 1996, "BANGLADESH GOVERNMENT THAT WORKS: REFORMING THE PUBLIC SECTOR”, Private Sector Development \& Finance Division Country Department 1 - South Asia Region, July 10.

[15]. Mukherjee, R., Gokcekus, O., Manning, N. \& Landell-mills, P., 2001, "Bangladesh: The experience and perceptions of public officials", Draft for Consultation, World Bank Technical Paper No. 507. Washington D.C.: The World Bank, October.

[16]. Sixth Five Year Plan (FY2011-FY2015), 2011, "Accelerating Growth and Reducing Poverty: Strategic Directions and Policy Framework”, Planning Commission, Ministry of Planning, Government of the People's Republic of Bangladesh.

[17]. United Nations, 2001, "World Public Sector Report: Globalization and the State", New York: Department of Economic and Social Affairs, United Nations.

[18]. World Bank, 1996, "Bangladesh Government that Works: Reforming the Public Sector", Oxford University Press, Dhaka. 